Jurnal Ekonomi, Bisnis dan Akuntansi (JEBA) Volume 21 Nomor 04 Tahun 2019

\title{
PENGARUH KUALITAS PELAYANAN TERHADAP KEPUASAN PASIEN RAWAT INAP DI RUMAH SAKIT UMUM DAERAH KABUPATEN MERAUKE
}

\author{
Wilhelmina Kosnan ${ }^{1 *}$ \\ 1Program Pascasarjana Magister Manajemen Universitas Jendral Soedirman Purwokerto \\ *Email corresponding author: wilhelminakosnan@gmail.com
}

\begin{abstract}
Abstrak
Penelitian ini bertujuan untuk menganalisis pengaruh kualitas layanan yang terdiri dari dimensi wujud fisik (tangible), keandalan (reliability), ketanggapan (responsiveness), jaminan (assurance) dan empati (empathy), terhadap kepuasan pasien rawat inap di Rumah Sakit Umum Daerah Kabupaten Merauke. Penelitian ini mengambil studi pada Rumah Sakit Umum Daerah Kabupaten Merauke. Populasi dalam penelitian ini adalah seluruh pasien yang menjalankan rawat inap di Rumah Sakit Umum Daerah Kabupaten Merauke periode Desember 2017-Januari 2018, sedangkan sampel penelitian berjumlah 100 orang yang dicari menggunakan teknik purposive sampling dengan rumus Sloom. Metode pengumpulan data yang digunakan dalam penelitian ini menggunakan metode kuesioner yang dibagikan kepada responden berisi atribut-atribut yang dijadikan sebagai indikator (alat ukur). Teknik analisis data dalam penelitian ini menggunakan analisis regresi linier berganda yang dioperasikan melalui program SPSS. Hasil penelitian menunjukkan bahwa: 1) Tangible berpengaruh terhadap kepuasan pasien rawat inap di Rumah Sakit Umum Daerah Kabupaten Merauke. 2) Reliability berpengaruh terhadap kepuasan pasien rawat inap di Rumah Sakit Umum Daerah Kabupaten Merauke. 3) Responsiveness berpengaruh terhadap kepuasan pasien rawat inap di Rumah Sakit Umum Daerah Kabupaten Merauke. 4) Assurance berpengaruh terhadap kepuasan pasien rawat inap di Rumah Sakit Umum Daerah Kabupaten Merauke dan 5) Emphaty berpengaruh terhadap kepuasan pasien rawat inap di Rumah Sakit Umum Daerah Kabupaten Merauke.
\end{abstract}

Kata kunci: kualitas layanan, kepuasan pasien.

\begin{abstract}
This study aims to analyze the effect of service quality which consists of tangible dimensions, reliability, responsiveness, assurance, and empathy, towards the satisfaction of hospitalized patients at Merauke Regency Regional General Hospital. This research takes a study at Merauke Regency Regional General Hospital. The population in this study were all patients who were hospitalized in the Merauke Regency General Hospital in the period December 2017-January 2018, while the study sample of 100 people was sought using a purposive sampling technique with the Sloom formula. Data collection methods used in this study used a questionnaire method that was distributed to respondents containing attributes that were used as indicators (measuring instruments). The data analysis technique in this study uses multiple linear regression analysis operated through the SPSS program. The results showed that: 1) Tangible influences the satisfaction of inpatients in Merauke Regency Regional General Hospital. 2) Reliability affects the satisfaction of inpatients at the Merauke Regency General Hospital. 3) Responsiveness influences the satisfaction of inpatients at the Regional General Hospital of Merauke Regency. 4) Assurance affects the satisfaction of inpatients in the Merauke Regency General Hospital and 5) Empathy affects the satisfaction of inpatients in the Merauke Regency General Hospital.
\end{abstract}

Keyword: service quality, patient satisfaction.

\section{PENDAHULUAN}

\section{Latar Belakang}

Penelitian ini untuk mengkaji pengaruh kualitas layanan yang terdiri dari dimensi wujud fisik (tangible), keandalan (reliability), ketanggapan (responsiveness), jaminan (assurance) dan empati (empathy) terhadap kepuasan pasien. Kualitas layanan merupakan pelayanan terbaik yang dilakukan oleh seseorang, kelompok atau lembaga yang memberi kepuasan bagi pelanggan 
atau masyarakat dan pada gilirannya kepuasan itu akan menciptakan loyalitas pelanggan atau masyarakat kepada seseorang/kelompok/lembaga yang memberikan pelayanan tersebut. Parasuraman et al (1988) berpendapat bahwa kualitan pelayanan memiliki lima dimensi yaitu 1) Tangibility, 2) Reliability, 3) Reponsivence, 4) Assurence, 5) Emphaty.

Kotler (dalam Supranto, 2006: 231), menjelaskan lima determinan kualitas jasa adalah sebagai berikut: 1) Berwujud (tangible), yaitu penampilan fasilitas fisik, peralatan, personil, dan media komunikasi. 2) Keandalan (reliability), yaitu kemampuan untuk melaksanakan jasa yang dijanjikan dengan tepat dan terpercaya. 3) Ketanggapan (responsiveness), yaitu kemauan untuk membantu pelanggan dan memberikan jasa dengan cepat atau ketanggapan. 4) Jaminan (assurance), yaitu mencakup pengetahuan dan kesopanan karyawan serta kemampuan mereka untuk menimbulkan kepercayaan dan jaminan atau assurance, dan 5) Empati (emphaty), yaitu syarat untuk peduli, memberi perhatian pribadi bagi pelanggan.

Kualitas memiliki hubungan yang sangat erat dengan kepuasan pelanggan, yaitu kualitas memberikan suatu dorongan kepada pelanggan untuk menjalani ikatan hubungan yang kuat dengan perusahaan. Dalam jangka panjang ikatan seperti ini memungkinkan perusahaan untuk memahami dengan saksama harapan pelanggan serta kebutuhan mereka Dengan demikian, perusahaan dapat meningkatkan kepuasan pelanggan yang pada gilirannya kepuasan pelanggan dapat menciptakan kesetiaan atau loyalitas pelanggan kepada perusahaan yang memberikan kualitas memuaskan.

Kepuasan pelanggan akan terpenuhi jika apa yang dirasakan melebihi dari apa yang diharapkan. Bila harapan tidak sesuai dengan apa yang dirasakan maka akan menimbulkan gap. Menurut Zeithaml dkk (1990) terdapat lima macam kesenjangan kualitas jasa yang memungkinkan kegagalan penyampaian jasa, yaitu: 1) Gap antara harapan pelanggan dengan persepsi manajemen atas harapan pelanggan, 2) Gap antara persepsi manajemen atas harapan pelanggan dengan spesifikasi kualitas jasa, 3) Gap antara spesifikasi kualitas dengan kualitas jasa yang sebenarnya diberikan, 4) Gap antara jasa yang diberikan dengan jasa yang dikomunikasikan dengan pelanggan, dan 5) Gap antara harapan pelanggan dan persepsi yang dibentuk dengan apa yang dia rasakan/diterima dari jasa tersebut.

Kepuasan adalah perasaan senang atau kecewa seseorang yang muncul setelah membandingkan antara presepsi atau kesannya terhadap kinerja atau hasil suatu produk dan harapan-harapannya (Kotler, 2004). Kepuasan pasien adalah persepsi pasien bahwa harapannya telah terpenuhi atau terlampaui (Gerson, 2004). Sedangkan kepuasan pasien berhubungan dengan mutu pelayanan rumah sakit. Dengan mengetahui tingkat kepuasan pasien, manajemen rumah sakit dapat melakuakan peningkatan mutu pelayanan. Prosentase pasien yang menyatakan puas terhadap pelayanan berdasarkan hasil survai dengan instrument yang berlaku (Indikator Kinerja Rumah Sakit, Depkes RI Tahun 2005).

\section{Model Penelitian}

Menurut Utama (2005: 5) indikator pelayanan kesehatan yang dapat menjadi prioritas menentukan kepuasan pasien adalah: kinerja tenaga dokter, kinerja tenaga perawat, kondisi fisik rumah sakit, makanan dan menu pasien, sistem administrasi pelayanan, pembiayaan, dan rekam medis. Pada penelitian ini variabel kualitas pelayanan yang akan diteliti adalah; berwujud, keandalan, daya tanggap, jaminan, empati.

Karakteristik pasien (responden) seperti; umur, jenis kelamin, lama perawatan, sumber biaya, diagnosa penyakit, pekerjaan, pendapatan, pendidikan, suku bangsa, tempat tinggal, kelas perawatan, status perkawinan, agama, dan preferensi. Akan tetapi beberapa hal tersebut yang 
diduga menjadi indikator kualitas pelayanan kesehatan dan mempengaruhi tingkat kepuasan pasien namun tidak menyeluruh dibahas dalam penelitian ini.

Pada penelitian ini, hubungan dan pengaruh: kualitas pelayanan dokter (medis), kualitas pelayanan perawat (paramedis), kualitas pelayanan sarana penunjang rumah sakit, dan kualitas pelayanan administrasi terhadap kepuasan pasien rawat inap di Rumah Sakit Umum Daerah Kabupaten Merauke, dijabarkan dalam kerangka teori penelitian seperti pada gambar 2.1. Berdasarkan teori di atas maka dalam penelitian ini penulis menetapkan hubungan antara variable independen dan variabel dependen digambarkan dalam model kualitas pelayanan terhadap kepuasan pasien dan dampaknya terhadap rawat inap di rumah sakit adalah sebagai berikut:

Spiritualitas di tempat kerja adalah membangun kerja individu dari pengalaman individu dalam berorganisasi yang mana merupakan passion dan energi dari pekerjaan mereka. Pengaruh kemauan tinggi dalam mengambil resiko terhadap kinerja menurut Wang Liao, Y, dkk (2016) yaitu pemahaman tentang komunikasi risiko yang terkait dengan risiko komunal dan berbagi informasi risiko. Berdasarkan penelitain terdahulu yang telah dibahas dan saran penelitian selanjutnya, berikut ini dikemukakan kerangka pemikiran yang diajukan dalam penelitian ini yang berfungsi sebagai penuntun sekaligus mencerminkan alur berfikir dan merupakan dasar bagi perumusan hipotesis, seperti yang terlihat pada dibawah ini:

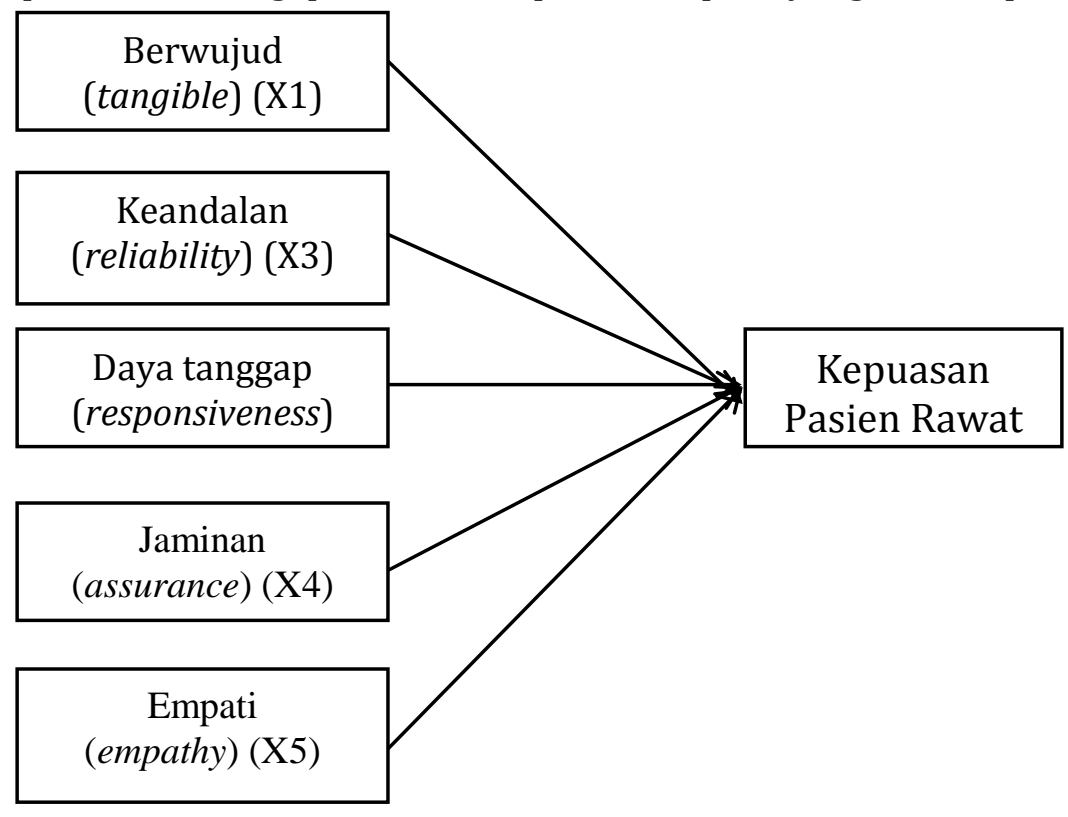

Gambar 1. Model Penelitian

\section{TINJAUAN PUSTAKA DAN PERUMUSAN HIPOTESIS}

\section{Tinjauan Pustaka}

$\underline{\text { Kualitas Layanan Kesehatan }}$

Kata kualitas mengandung banyak definisi dan makna karena orang yang berbeda-beda akan mengartikannya secara berlainan, seperti kesesuian dengan persyaratan atau tuntutan, kecocokan untuk pemakaian perbaikan berkelanjutan, bebas dari kerusakan atau cacat, pemenuhan kebutuhan pelanggan, melakukan segala sesuatu yang membahagiakan. Dalam perspektif Total Quality Management (TQM) kualitas dipandang secara lebih luas, yaitu tidak hanya aspek hasil yang ditekankan, tetapi juga meliputi proses, lingkungan dan manusia. 
Kualitas hidup kerja harus merupakan suatu pola pikir (mindset), yang dapat menterjemahkan tuntutan dan kebutuhan pasar konsumen dalam suatu proses manajemen dan proses produksi barang atau jasa secara terus menerus atau tanpa hentinya sehingga memenuhi persepsi kualitas pasar konsumen tersebut.

\section{$\underline{\text { Kepuasan Pasien }}$}

Kepuasan adalah perasaan senang atau kecewa seseorang yang muncul setelah membandingkan antara presepsi atau kesannya terhadap kinerja atau hasil suatu produk dan harapan-harapannya (Kotler, 2004). Kepuasan pasien adalah persepsi pasien bahwa harapannya telah terpenuhi atau terlampaui (Gerson, 2004). Sedangkan kepuasan pasien berhubungan dengan mutu pelayanan rumah sakit. Dengan mengetahui tingkat kepuasan pasien, manajemen rumah sakit dapat melakukan peningkatan mutu pelayanan. Persentase pasien yang menyatakan puas terhadap pelayanan berdasarkan hasil survai dengan instrument yang berlaku (Indikator Kinerja Rumah Sakit, Departemen Kesehatan Republik Indonesia Tahun 2005). Kepuasan pasien adalah suatu prioritas yang akan membantu perawat dalam memberikan pelayanan keperawatan agar pasien mau berpartisipasi selama perawatan.

\section{Perumusan Hipotesis}

Tangible terhadap kepuasan pasien

H1: Tangible berpengaruh terhadap kepuasan pasien rawat inap di RSUD Kabupaten Merauke Reliability terhadap kepuasan pasien

H2: Reliability berpengaruh terhadap kepuasan pasien rawat inap di RSUD Kabupaten Merauke Responsiveness terhadap kepuasan pasien

H3: Responsivenes berpengaruh terhadap kepuasan pasien rawat inap di RSUD Kabupaten Merauke

Assurence terhadap kepuasan pasien

H4: Assurence berpengaruh terhadap kepuasan pasien rawat inap di RSUD Kabupaten Merauke. Emphaty terhadap kepuasan pasien

H5: Emphaty berpengaruh terhadap kepuasan pasien rawat inap di RSUD Kabupaten Merauke.

\section{METODE PENELITIAN}

Penelitian ini dimaksudkan untuk mengungkapkan gambaran mengenai pengaruh kualitas pelayanan terhadap kepuasan pasien rawat inap di rumah sakit umum daerah kabupaten merauke. Berdasarkan masalah yang diteliti maka metode yang digunakan dalam penelitian ini adalah metode deskriptif dengan pendekatan kuantitatif yang ditunjang oleh studi kepustakaan. Metode deskriptif merupakan metode yang dipilih karena masalah yang diambil terpusat pada masalah aktual dan berada pada saat penelitian dilaksanakan dan menggunakan pendekatan kuantitatif dengan mendistribusikan angket yang berisi keterangan setiap variabel yang ingin diteliti dan kemudian dilakukan analisis penghitungan secara statistik (Susyanto, 2019)

\section{Populasi dan Sampel}

Pada penelitian ini populasinya mencakup seluruh pasien yang menjalankan rawat inap di Rumah Sakit Umum Daerah Kabupaten Merauke periode Desember 2017-Januari 2018. Sampel yaitu sebagian dari populasi yang hendak diteliti dan dianggap bisa mewakili keseluruhan populasi (Singarimbun, 1997: 112). Teknik pengambilan sampel menggunakan teknik purposive sampling yaitu teknik penentuan sampel jika informasi untuk data yang diambil dari target spesifik, dengan cara mengambil sampel dengan kriteria tertentu (Sugiyono, 2003), yaitu 
dengan kriteria sedang dirawat minimal sudah 2 hari. Untuk mengetahui beberapa banyak sampel minimal yang mewakili populasi para pasien rawat inap di Rumah Sakit Umum Daerah Kabupaten Merauke maka digunakan cara interval taksiran. Penelitian mengambil jumlah sampel sebesar 100 orang. Penyebaran kuesioner pada responden dilakukan pada bulan Januari 2018. Jadi jumlah sampel yang diambil dalam penelitian ini sebanyak 100 orang. Daftar pertanyaan diberikan kepada pasien rawat inap pada Rumah Sakit Umum Daerah Kabupaten Merauke.

\section{Metode Analisis}

Metode analisa data yang digunakan dalam penelitian ini adalah; 1) Uji validitas dan reliabilitas data, 2) Uji asumsi klasik yang terdiri dari; Uji normalitas, Uji multikolinieritas, Uji Heteroskedastisitas, 3) Analisis agresi linier berganda untuk mengetahui pengaruh variabel independen yang terdiri dari berwujud (tangible) $\left(\mathrm{X}_{1}\right)$, keandalan (reliability) $\left(\mathrm{X}_{2}\right)$, ketanggapan (responsiveness) $\left(\mathrm{X}_{3}\right)$, jaminan (assurance) $\left(\mathrm{X}_{4}\right)$, dan empati (emphaty) $\left(\mathrm{X}_{5}\right)$ terhadap variabel dependen yaitu kepuasan pasien $(\mathrm{Y})$. Analisis ini digunakan untuk mengukur pengaruh kualitas pelayanan terhadap kepuasan pasien rawat inap di Rumah Sakit Umum Dearah Kabupaten Merauke menggunakan level of significant (a) sebesar 5\%.

\section{HASIL PENELITIAN DAN PEMBAHASAN}

\section{Ringakasan analisis regresi}

\begin{tabular}{lcccl}
\hline \multicolumn{1}{c}{ Variabel Penelitian } & Koefisien & t & Sig & Simpulan \\
\hline Tangibel & 0,317 & 2,786 & 0,006 & Signifikan \\
Reliability & 0,346 & 3,062 & 0,003 & Signifikan \\
Responsiveness & 0,368 & 3,045 & 0,003 & Signifikan \\
Assurance & 0,273 & 2,390 & 0,019 & Signifikan \\
Empathy & 0,320 & 3,773 & 0,000 & Signifikan \\
F & & 23,827 & \\
Sig & & $0,000^{\mathrm{b}}$ & \\
$\mathrm{R}^{2}$ & & 0,536 & \\
\hline
\end{tabular}

\section{Uji t}

Uji statistik pada dasarnya menunjukan seberapa jauh pengaruh satu variabel penjelas/independen secara parsial dalam menerangkan variasi variabel dependen. Secara keseluruhan dapat disimpulkan bahwa: a) Hipotesis 1 menyatakan bahwa dimensi tangibel berpengaruh positif signifikan terhadap kepuasan pasien. Hasil analisis regresi menunjukan nilai t hitung untuk variabel tangibel 2,786 dengan nilai signifikansi 0,006 , karena nilai t hitung lebih besar dari $t$ tabel 1,6602 $(2,786>1,6602)$ dan nilai signifikansi kurang dari 0,05 $(0,006<0,05)$, maka dapat disimpulkan bahwa hipotesis tersebut diterima, b) Hipotesis 2 menyatakan bahwa variabel dimensi reliability berpengaruh positif signifikan terhadap kepuasan pasien. Hasil analisis regresi menunjukan nilai t hitung untuk dimensi reliability 3,062 dengan nilai signifikansi 0,003, karena nilai t hitung lebih besar dari t tabel 1,6602 $(3,062>1,6602)$ dan nilai signifikansi kurang dari 0,05 $(0,003<0,05)$, maka dapat disimpulkan bahwa hipotesis tersebut diterima, c) Hipotesis 3 menyatakan bahwa variabel dimensi responsiveness berpengaruh positif signifikan terhadap kepuasan pasien. Hasil analisis regresi menunjukan nilai t hitung untuk dimensi responsiveness 3,045 dengan nilai signifikansi 0,003, karena nilai t hitung lebih besar dari t tabel 1,6602 $(3,045>1,6602)$ dan nilai signifikansi kurang 
dari 0,05 $(0,003<0,05)$, maka dapat disimpulkan bahwa hipotesis tersebut diterima. d) Hipotesis 4 menyatakan bahwa variabel dimensi assurance berpengaruh positif signifikan terhadap kepuasan pasien. Hasil analisis regresi menunjukan nilai t hitung untuk dimensi assurance 2,390 dengan nilai signifikansi 0,019, karena nilai t hitung lebih besar dari t tabel 1,6602 $(2,390>1,6602)$ dan nilai signifikansi kurang dari $0,05(0,019<0,05)$, maka dapat disimpulkan bahwa hipotesis tersebut diterima. e) Hipotesis 5 menyatakan bahwa variabel dimensi empathy berpengaruh positif signifikan terhadap kepuasan pasien. Hasil analisis regresi menunjukan nilai thitung untuk dimensi empathy 3,773 dengan nilai signifikansi 0,000, karena nilai t hitung lebih besar dari t tabel 1,6602 $(3,773>1,6602)$ dan nilai signifikansi kurang dari 0,05 $(0,000<0,05)$, maka dapat disimpulkan bahwa hipotesis tersebut diterima.

\section{Uji F}

Berdasarkan hasil analisis regresi dapat dilihat bahwa nilai $\mathrm{F}$ hitung 23,872 dengan nilai signifikansi 0,000 $(<0,05)$, maka dapat disimpulkan bahwa terdapat pengaruh secara bersamasama (simultan) antara dimensi tangibels, reliability, responsiveness, assurance dan empathy terhadap kepuasan pasien rawat inap di RSUD Merauke.

\section{Koefisien korelasi $(R)$ dan determinasi $\left(R^{2}\right)$}

Berdasarkan hasil analisis regresi didapatkan nilai koefisien determinasi ( $\mathrm{R}$ square) variabel independen terhadap kepuasan pasien sebesar 0,536 artinya besarnya pengaruh secara simultan variabel independen (tangibels, reliability, responsiveness, assurance dan empathy) terhadap kepuasan pasien rawat inap di RSUD Merauke sebesar 53,6\% dan sisanya yaitu sebesar 46,4\% dipengaruhi oleh variabel lain yang tidak diteliti dalam model penelitian ini.

\section{Pembahasan Hasil Penelitian}

\section{Pengaruh tangible terhadap kepuasan pasien rawat inap di RSUD Merauke.}

Berdasarkan hasil analisis regresi, dapat diketahuai bahwa dimensi tangibels berpengaruh secara parsial terhadap kepuasan pasien rawat inap di RSUD Merauke. Hasil ini menunjukkan hipotesis satu $\left(\mathrm{H}_{1}\right)$ diterima, yang berarti bahwa dimensi tangibels berpengaruh positif signifikan terhadap kepuasan pasien. Hasil penelitian ini sejalan dengan penelitian yang dilakukan oleh Santoso (2012) yang menyatakan bahwa bukti fisik (tangible) mempunyai pengaruh positif dan signifikan terhadap kepuasan pasien. Semakin baik persepsi pelanggan terhadap bukti fisik (tangible) maka kepuasan pasien akan semakin tinggi. Dan jika persepsi pasien terhadap bukti fisik (tangible) buruk, maka kepuasan semakin rendah. Suatu rumah sakit agar bisa operasional, tidak cukup mempunyai sumber daya manusia saja, tetapi harus didukung pula oleh fasilitas penunjang Rumah Sakit baik penunjang medis maupun non medis, serta sarana penunjang rumah sakit antara lain meliputi: laboratorium, instalasi farmasi, radiologi, pelayanan makan pasien, dan lain-lain. Fasilitas penunjang rumah sakit juga sangat menentukan terhadap kualitas pelayanan rumah sakit sehingga mempengaruhi kepuasan pasien, khususnya rawat inap (Nova, 2010). Selain itu Gibson (2007) menyatakan bahwa fasilitas merupakan sarana maupun prasarana yang penting dalam usaha meningkatkan kepuasan seperti memberi kemudahan, memenuhi kebutuhan dan kenyamanan bagi pengguna jasa. Apabila fasilitas yang disediakan sesuai dengan kebutuhan, maka konsumen akan merasa puas. Pasien akan memberikan penilaian (reaksi afeksi) terhadap sarana dan prasarana kesehatan yang terkait dengan penyelenggaraan pelayanan kesehatan. Penilaian terhadap kondisi rumah sakit (kualitas baik atau buruk) merupakan gambaran kualitas rumah sakit seutuhnya berdasarkan pengalaman subjektif individu pasien.

Pengaruh reliability terhadap kepuasan pasien rawat inap di RSUD Merauke. 
Berdasarkan hasil analisis regresi, dapat diketahuai bahwa dimensi reliability berpengaruh secara parsial terhadap kepuasan pasien rawat inap di RSUD Merauke. Hasil ini menunjukkan hipotesis dua $\left(\mathrm{H}_{2}\right)$ diterima, yang berarti bahwa dimensi reliability berpengaruh positif signifikan terhadap kepuasan pasien. Hasil penelitian ini sesuai dengan penelitian yang dilakukan oleh Penelitian yang dilakukan Atmawati dan Wahyudin (2007) serta Hardiyati (2010) yang menyatakan bahwa variabel kehandalan (reliability) berpengaruh positif terhadap kepuasan konsumen. Kehandalan menurut Sayed et al (2013) juga merupakan faktor paling dominan yang mempengaruhi kepuasan pelanggan. Dalam memberikan pelayanan kepada pasien, pelayan harus benar-benar menyadari bahwa penyembuhan seseorang bukan hanya ditentukan oleh obat-obatan yang diberikannya, tetapi juga dipengaruhi oleh cara pelayanan yang diperlihatkan para petugas kesehatan seperti sikap, ketrampilan sertapengetahuannya (Gonzales, 2007). Reliability merupakan dimensi dimana Rumah Sakit mempersiapkan petugaspetugas yang mempunyai dedikasi tinggi, seperti: terampil, ramah, sopan, simpati, luwes, penuh pengertian, mempunyai kemampuan komunikasi dengan baik (Snook, 2001). Mayoritas jawaban responden dalam dimensi reliability menyatakan bahwa petugas dari RSUD Merauke mayoritas menguasai pekerjaanya. Jika petugas rumah sakit mempunyai kemampuan umum tentang rumah sakit, menguasai pekerjaannya, dan yang lebih penting adalah petugas yang mempunyai kemampuan komunikasi dan interpersonal yang baik maka pelanggan akan perasa puas akan pelayanan yang diberikan (Goldberg, 1996).

\section{Pengaruh responsivenes terhadap kepuasan pasien rawat inap di Rumah Sakit Umum Daerah Kabupaten Merauke.}

Berdasarkan hasil analisis regresi, dapat diketahuai bahwa dimensi responsiveness berpengaruh secara parsial terhadap kepuasan pasien rawat inap di RSUD Merauke. Hasil ini menunjukkan hipotesis tiga $\left(\mathrm{H}_{3}\right)$ diterima, yang berarti bahwa dimensi responsiveness berpengaruh positif signifikan terhadap kepuasan pasien. Hasil penelitian ini sejalan dengan penelitian yang dilakukan oleh Sharmila dan Krishnan (2013) yang meneliti mutu pelayanan di rumah sakit swasta di Chenai India dengan 385 responden menemukan bahwa daya tanggap (responsiveness) berhubungan secara bermakna dengan kepuasan pasien. Daya tanggap (responsiveness) mempunyai pengaruh positif dan signifikan terhadap kepuasan pasien. Semakin baik persepsi pelanggan terhadap daya tanggap (responsiveness) maka kepuasan pasien akan semakin tinggi.

Rumah sakit merupakan lokasi yang secara umum merupakan tempat seseorang untuk mendapatkan pelayanan kesehatan. Oleh sebab itu penyedia jasa pelayanan kesehatan harus mampu menanggapi setiap keluhan pasien. Dengan demikian daya tanggap yang tinggi dari pihak pengelola rumah sakit akan memberikan rasa kepercayaan pada pasien bahwa mereka akan selalu tertolong. Badri et al (2009) dalam penelitian tentang mutu pelayanan kesehatan dan faktor-faktor yang mempengaruhi kepuasan pasien mengemukakan bahwa dimensi responsiveness sebagai salah satu dari indikator yang selalu dimasukkan dalam berbagai penelitian yang berhubungan dengan mutu pelayanan. Daya tanggap (responsiveness) juga dapat dilihat dari bagimana sikap ahli medis yang diinginkan pasien pada saat menanganinya. Penelitian dari Essiam (2013) dengan 400 responden di Ghana menunjukkan bahwa responsiveness sebagai faktor paling dominan dalam hubungan dengan kepuasan pasien.

\section{Pengaruh assurance terhadap kepuasan pasien rawat inap di RSUD Merauke.}

Berdasarkan hasil analisis regresi, dapat diketahuai bahwa dimensi assurance berpengaruh secara parsial terhadap kepuasan pasien rawat inap di RSUD Merauke. Hasil ini menunjukkan hipotesis empat $\left(\mathrm{H}_{4}\right)$ diterima, yang berarti bahwa dimensi assurance berpengaruh positif signifikan terhadap kepuasan pasien. Hasil ini sesuai dengan penelitian yang dilakukan Mustofa 
(2008) terhadap 30 responden tentang hubungan antara persepsi pasien terhadap dimensi mutu pelayanan keperawatan menemukan bahwa ada hubungan yang bermakna antara persepsi pasien terhadap dimensi jaminan dengan kepuasan pasien. Arsanam et al (2014) menemukan jaminan merupakan dimensi yang paling dominan. Selain itu juga penelitian yang dilakukan oleh Nasarudin et al (2013) dalam penelitian terhadap mutu pelayanan di bagian Fisioterapi menemukan bahwa dimensi jaminanberhubungan secara bemakna dengan kepuasan pasien.

Assurance mencakup pengetahuan, kemampuan, kesopanan, sifat dapat dipercaya yang dimiliki para staf, dan bebas dari bahaya, risiko menanamkan kepercayaan kepada pelanggan, sikap sopan dan kemampuan karyawan dalam menjawab pertanyaan pelanggan. Assurance mempunyai pengaruh positif dan signifikan terhadap kepuasan pasien. Semakin baik persepsi pelanggan terhadap jaminan (assurance) maka kepuasan pasien akan semakin tinggi. Jika persepsi pasien terhadap jaminan (assurance) buruk maka, kepuasan pasien akan semakin rendah (Santoso, 2012). Dimensi assurance dapat dilihat berdasarkan bagaimana pengetahuan yang dimiliki oleh petugas rumah sakit dalam menjawab pertanyaan dari pasien. Jaminan (assurancce) yang mencakup pengetahuan dan ketrampilan karyawan dalam melayani kebutuhan pasien, etika para pegawai, dan jaminan keamanan dari rumah sakit. Adanya jaminan keamanan dari suatu rumah sakit akan membuat pasien merasa aman dan tanpa ada rasa raguragu untuk berobat, disamping itu jaminan dari suatu rumah sakit akan berpengaruh pada kepuasan pasien karena apa yang diinginkan pasien dapat dipenuhi oleh rumah sakit yaitu dengan pengetahuan dan ketrampilan dari perawat dan dokter (Pratiwi dan Susanto, 2016).

\section{Pengaruh emphaty terhadap kepuasan pasien rawat inap di RSUD Merauke.}

Berdasarkan hasil analisis regresi, dapat diketahuai bahwa dimensi emphaty berpengaruh secara parsial terhadap kepuasan pasien rawat inap di RSUD Merauke. Hasil ini menunjukkan hipotesis lima $\left(\mathrm{H}_{5}\right)$ diterima, yang berarti bahwa dimensi emphaty berpengaruh positif signifikan terhadap kepuasan pasien. Dimensi ini dilihat berdasarkan bagaimana pihak Rumah Sakit dalam meyakinkan pelanggannya bahwa mereka itu adalah unik dan istimewa dan dapat digambarkan dengan perhatian secara personal kebutuhan spesifik dan terhadap keluhan terhadap pasien dimana pada umumnya pasien ingin diperlakukan dan diperhatikan secara khusus oleh pihak pengelola rumah sakit. Hal ini akan menambah kepercayaan mereka terhadap rumah sakit.

Hasil penelitian ini sejalan dengan penelitian yang dilakukan oleh Pratiwi dan Susanto (2016) yang menyatakan bahwa emphaty (X5) mempunyai pengaruh yang positif terhadap kepuasan pasien. Berdasarkan hasil penelitian yang dilakukan oleh Nurdiana (2017) dimensi emphaty memang sering dianggap tidak terlalu penting oleh para perawat. Namun bagi pasien dari kalangan tertentu (menengah ke atas) unsur ini menjadi hal yang cukup penting. Mereka merasa ego, status, dan gengsinya tetap terpelihara atau bahkan terus menerus ditingkatkan dihadapan banyak orang.

Al Khattab dkk (2011) menemukan keluhan utama terhadap pelayanan di RS pemerintah adalah daya tanggap dan empati yang berhubungan dengan kelambatan pelayanan dan singkatnya waktu konsultasi. Kekurangan tersebut merupakan alasan utama persepsi yang kurang tentang kualitas pelayanan di RS pemerintah. Sedangkan Faisal dkk (2013) menemukan adanya hubungan antara dimensi ketanggapan dan kepedulian (empati) dengan kepuasan. Ruang rawat inap merupakan tempat yang paling lama bagi pasien untuk tinggal dibandingkan unit-unit lainnya. Disinilah harapan serta keyakinan pasien akan memperoleh pelayanan yang sebaik-baiknya, sedang rumah sakit berusaha semaksimal mungkin dapat memberikan pelayanan sesuai harapan pasien. 


\section{KESIMPULAN DAN IMPLIKASI}

\section{Kesimpulan}

Berdasarkan hasil penelitian yang telah dilakukan dapat diambil kesimpulan sebagai berikut: a) Tangible berpengaruh terhadap kepuasan pasien rawat inap di Rumah Sakit Umum Daerah Kabupaten Merauke, b) Reliability berpengaruh terhadap kepuasan pasien rawat inap di Rumah Sakit Umum Daerah Kabupaten Merauke, c) Responsivenes berpengaruh terhadap kepuasan pasien rawat inap di Rumah Sakit Umum Daerah Kabupaten Merauke, d) Assurance berpengaruh terhadap kepuasan pasien rawat inap di Rumah Sakit Umum Daerah Kabupaten Merauke, e) Emphaty berpengaruh terhadap kepuasan pasien rawat inap di Rumah Sakit Umum Daerah Kabupaten Merauke..

\section{Implikasi}

Implikasi dari hasil penelitian mencakup implikasi teoritis dan praktis

Implikasi teoritis

Hasil penelitian ini memperkuat hasil penelitian yang pernah dilakukan sebelumnya bahwa tangibles, reliability, responsiveness, assurance dan emphaty berpengaruh terhadap kepuasan pasien.

Implikasi praktis

Karena suatu bentuk jasa tidak bisa dilihat, tidak bisa dicium dan tidak bisa diraba maka aspek wujud fisik menjadi penting sebagai ukuran dari pelayanan. Pasien akan menggunakan indera penglihatan untuk menilai suatu kulitas pelayanan. Bukti fisik yang baik akan mempengaruhi persepsi pasien. Pada saat yang bersamaan aspek ini juga merupakan salah satu sumber yang mempengaruhi harapan pasien. Karena dengan bukti fisik yang baik maka harapan pasien menjadi lebih tinggi. Oleh karena itu merupakan hal yang penting bagi rumah sakit untuk mengetahui seberapa jauh aspek wujud fisik yang paling tepat, yaitu masih memberikan impresi positif terhadap kualitas pelayanan yang diberikan tetapi tidak menyebabkan harapan pasien yang terlalu tinggi sehingga dapat memenuhi kebutuhan pasien dan memberikan kepuasan kepada pasien. Hubungan pasien dengan petugas Rumah Sakit, dapat dijabarkan dengan pertanyaan petugas yang mempunyai kepribadian baik yang mendukung jalannya pelayanan prima terjadi yang menyangkut keramahan, informasi yang diberikan, sejauh mana tingkat komunikasi, dukungan, tanggapan dokter/perawat di ruangan IGD, rawat jalan, rawat inap, farmasi, kemudahan dokter/perawat dihubungi, keteraturan pemberian makanan, obat, pengukuran suhu dan lain sebagainya.

\section{Keterbatasan Penelitian}

Keterbatasan-keterbatasan yang dihadapi peneliti dalam melaksanakan penelitian ini adalah sebagai berikut: a) Periode penelitian cukup singkat sehingga pengukuran dalam studi ini bersifat sesaat (concurrent). Desain studi yang memiliki rentang waktu lebih lama diharapkan dapat mencapai hasil yang lebih optimal daripada yang ditemukan dalam studi ini, b) Adanya keengganan dari pasien untuk menjawab atau mengisi kuesioner yang diberikan selain itu juga pertanyaan yang bersifat terbuka mayoritas tidak dijawab oleh pasien, sehingga hasil penelitian yang lebih detail tidak dapat terungkap dalam penelitian ini. 


\section{DAFTAR PUSTAKA}

Alma, Buchari. (2009). Manajemen Pemasaran dan Pemasaran Jasa. Edisi Revisi. Cetakan Kelima. CV. Alfabeta. Bandung.

Al Khattab, S. dan A.H. Aborumman. (2011). Health Service Quality: Comparing Public and Private Hospitals in Jordan. International Business Management Vol 5 No. 5, pp. 247-254.

Azwar, A. (1996). Menjaga Mutu Pelayanan Kesehatan. Jakarta, Pustaka Sinar Harapan.

Badri, M.A., S. Attia dan A.M. Ustadi. (2008). Healthcare quality and moderators of patient satisfaction: testing for causality. International Journal of Health Care Quality Assurance Vol. 22 No. 4, pp. 382-410.

Goldberg, A. (1996). Hospital Departemen Profil. USA: American Hospital Publishing, Co. INC.

Gonzales. (2007). Cultur, Diseas and Healing Studies in Medical Anthropology. New York: Millan Publishing, Co. INC.

Imelda, S dan Nahrisah, E. (2015). Analisis Tingkat Mutu Pelayanan Rawat Inap dalam Upaya Peningkatan Kepuasan Pasien di RSUP Adam Malik Medan. Jurnal Managemen STIE Harapan Medan.

Khasanah, I dan Pertiwi, O,D. (2012). Analisis Pengaruh Kualitas Pelayanan Terhadap Kepuasan Konsumen RS St. Elisabeth Semarang. Jurnal Managemen Universitas Diponegoro.

Keputusan Menteri Kesehatan Nomor HK.02.02/Menkes/52/2015 Tentang Rencana strategis Kementerian Kesehatan Tahun 2015-2019

Keputusan Menteri Kesehatan Republik Indonesia Nomor.129/Menkes SK/II/2008 Tentang Standar Pelayanan Minimal Rumah Sakit. Jakarta.

Mustofa, A. (2008). Hubungan Antara Persepsi Pasien Terhadap Dimensi Mutu Pelayanan Keperawatan Dengan Kepuasan Pasien di Ruang Rawat Inap Rumah Sakit Umum PKU Muhammadiyah Temanggung. Jurnal Keperawatan Vol. 1 No. 2, pp. 23-37

Purwoastuti, E dan Walyani, E.S. (2015). Mutu Pelayanan Kesehatan dan kebidanan. Cetakan pertama,Yogyakarta: Pustaka Baru Press.

Pratiwi, Siska dan Susanto. (2016). Pengaruh Kualitas Pelayanan Terhadap Kepuasan Pasien Rawat Inap di Rumah Sakit Sultan Immanudin Pangkalan Bun Kalimantan Tengah. Jurnal Asosiasi Dosen Muhammadiyah Magister Administrasi Rumah Sakit Vol.2 No. 2 Juli 2016

Santoso, Samiaji. (2012). Analisis Pengaruh Kualitas Pelayanan Terhadap Kepuasan Pasien Rawat Inap Kelas III Pada RS. Roemani Muhammadiyah Semarang. Skripsi. Semarang: UNDIP.

Sharmila, S. dan J. Krishnan. (2013). Has the Servic Quality in Private Corporate Hospitals Meet the Patient Expectations? A Study About Hospital Quality in Chennai. Asia Pacific Journal of Marketing \& Management Vol 2 No. 1, pp. 19-35. 
Snook, JR. D. (2001). Hospital What They are and How They Work. Maryland London: An Aspen Publication Rock Ville

Sugiyono. (2010). Metode Penelitian Kuantitatif Kualitatif Dan $R \& D$. Cetakan kesepuluh, Bandung: Alfabeta.

Sumantri, H. S. (2011). Metodologi Penelitian Kesehatan. Cetakan pertama, Jakarta: Kencana.

Supranto. (2001). Statistik: Teori dan Aplikasi. Jakarta, Erlangga.

Supranto, J. (2011). Pengukuran Tingkat Kepuasan Pelanggan, Untuk Menaikkan Pangsa Pasar. Cetakan keempat. Jakarta: PT Rineka Cipta.

Susyanto, Hendro. (2019). Pengaruh Kepemimpinan, Keterlibatan Karyawan Dan Kepuasan Kerja Terhadap Kesiapan Untuk Berubah Dalam Menghadapi Perubahan Organisasi. Jurnal Ekonomi Bisnis dan Akuntansi. Vol 21 (01).

Yulianti, N dan Madiawati, P, N. (2015). Pengaruh Kualitas Pelayanan Terhadap Kepuasan Pasien pada Unit Rawat Inap Rumah Sakit Dr. Hasan Sadikin Bandung. Jurnal Administrasi Universitas Telkom.

Zeithmal dan Binner. (1996). Menjaga Mutu Pelayanan di Rumah Sakit (Quality Assurance). Persi. Jakarta.

Zeithaml, Berry and Parasuraman. (1996). "The Behavioral consequences of service quality". Journal of Marketing. pp. 31-46. 